\title{
Mechanical Issue
}

National Cancer Institute

\section{Source}

National Cancer Institute. Mechanical Issue. NCI Thesaurus. Code C62961.

Problems associated with mechanical actions or defects of the device, which includes any moving parts or subassemblies, etc. 